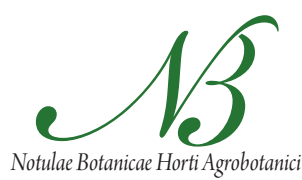

Cluj-Napoca

\title{
Seed Development and Quality in Maize Cultivars
}

\author{
Kazem GHASSEMI-GOLEZANI, Zahra TAJBAKHSH, Yaeghoob RAEY \\ University of Tabriz, Faculty of Agriculture, Department of Agronomy and Plant Breeding, Tabriz, Iran; golezani@gmail.com
}

\begin{abstract}
In order to evaluate seed development and quality of maize (Zea mays) cultivars ('DC-370', 'SC-500', 'OSSK-602' and 'SC-604'), a split plot experiment (using R.C.B. design) with three replicates was conducted in 2009 at the Research Farm of the Faculty of Agriculture, University of Tabriz, Iran. Seeds were harvested at five day intervals in eight stages. Subsequently, the quality of seed samples was determined in the laboratory. Germination percentage and seedling dry weight were enhanced, but electrical conductivity of seed leachates was reduced with increasing seed weight on mother plant. Maximum seed quality of maize cultivars was attained at the end of seed filling phase. Seed quality at earlier harvests was low, because of immaturity. Differences in maximum seedling dry weight of maize cultivars were attributed to variation in genetic constitution. It was concluded that in maize cultivars, maximum seed quality could be achieved at physiological maturity.
\end{abstract}

Keywords: germination, maize, physiological maturity, seed development, seed quality

\section{Introduction}

Rapid and synchronized seed germination and seedling emergence are crucial for achieving an optimal crop stand and high productivity. By a good seedling establishment, plant life cycle would be guaranteed a strong plant, with a good plant density and uniformity (Harris et al., 1999; Ghassemi-Golezani, 1992; Ghassemi-Golezani et al., 2010a,b). This is particularly true for crops such as maize (Zea mays L.), which has not the capacity to adjust to incomplete stand by tillering (Ghiyasi et al., 2008).

High quality seeds may improve crop yield via high and rapid emergence of seedlings, leading to the production of vigorous plants and optimum stand establishment under a wide range of environmental conditions (Ghassemi-Golezani, 1992). Therefore, cultivation of high quality seeds is essential for satisfactory yield production. Several reports have shown poor stand establishment caused by low seed quality and consequently yield loss in corn (Cruz-Garcia et al., 1995), wheat (Ganguli and Sen-Mandi, 1990; Ram and Wiesner, 1988), barley (Abdalla and Roberts, 1969; Copeland and Mc Donald, 2001; Kim et al., 1989; Matthews and Collins, 1975; Perry, 1980a; Samarah and AlKofahi, 2008) soybean (Vieira et al., 1999), cottonseed, (Iqbal et al., 2002) and oilseed rape (Ghassemi-Golezani et al., 2010a,b).

According to some researchers (Harington, 1972; Tekrony and Egli, 1997) mass maturity (end of seed filling phase) described as physiological maturity is a good sign of achieving maximum seed quality on the mother plant. In contrast, many reports on various crops suggest that maximum seed quality is attained after mass maturity (Pieta Filho and Ellis, 1991; Ellis and Pieta Filho, 1992; Demir and Ellis, 1992, 1993; Sanhewe and Ellis, 1996; GhassemiGolezani and Mazloomi-Oskooyi, 2008). These contradictory results may relate to differences in harvest time and species (Tekrony and Egli, 1997; Ghassemi-Golezani and Hosseinzadeh-Mahootchy, 2009).

Hanway (1963) described accumulation of reserves in corn seeds through regressive equations as a function of time. The maximum values of these regressive equations were considered as the end of seed filling phase. Rench and Shaw (1971) described the point of maximum physiological quality of corn seeds with moisture content and dry weight accumulation, and observed that those characteristics vary with genotype and seeding date. Thus, this research was conducted to investigate the changes in seed quality of maize cultivars at different stages of seed development and maturity.

\section{Materials and methods}

A split plot experiment (using RCB design) with three replications was conducted in 2009 at the Research Farm of the Faculty of Agriculture, University of Tabriz, Tabriz, Iran (Latitude $38^{\circ} 05^{\prime} \mathrm{N}$, Longitude $46^{\circ} 17^{\prime} \mathrm{E}$, Altitude $1360 \mathrm{~m}$ above sea level), in order to determine the best developmental stage for harvest and production of high quality seeds from four maize (Zea mays) cultivars. Harvest times were located in sub plots and cultivars ('DC370', 'SC-500', 'OSSK-602' and 'SC-604') were allocated to main plots. The climate is characterized by mean annual precipitation of $245.75 \mathrm{~mm}$ per year and mean annual temperature of $10^{\circ} \mathrm{C}$.

Each plot had 6 rows of $6 \mathrm{~m}$ length, spaced $25 \mathrm{~cm}$ apart. Seeds were treated with Benomyl at a rate of $1.5 \mathrm{~g} /$ 
$\mathrm{kg}$ before sowing. The seeds were then sown at mid-May in $5 \mathrm{~cm}$ depth of a sandy loam soil. All Plots were irrigated after $70 \mathrm{~mm}$ evaporation from class A pan. Plots were fertilized with $100 \mathrm{~kg} / \mathrm{ha}$ Ammonium phosphate. Weeds were controlled by hand during crop growth and development as required.

Seeds were harvested at five day intervals in eight stages. Seed moisture content was determined in accordance with ISTA rules (2010). Subsequently, seeds were air dried at $18-20^{\circ} \mathrm{C}$ and 100 seed weight of each sample was determined. Seed samples within separate sealed bags were then placed in a refrigerator at $3-5^{\circ} \mathrm{C}$. Four replicates of 25 seeds from each sample were tested for germination in sterilized filter papers. These papers were incubated at $20 \pm 1^{\circ} \mathrm{C}$ for 14 days and germinated seeds (protrusion of radicle by 2 $\mathrm{mm}$ ) were counted every day up to 14 days. Rate of seed germination was calculated according to Ellis and Roberts (1980). At the end of each test, numbers of normal and abnormal seedlings were counted (ISTA, 2010) and germination percentage was calculated. Seedlings were then dried in an oven at $80^{\circ} \mathrm{C}$ for 24 hours (Perry, 1977) and mean seedling dry weight for each treatment at each replicate was determined.

Two replicates of 50 seeds from each sample were weighed (SW1 and SW2) and then seeds of each repli- cate immersed in $250 \mathrm{ml}$ deionized water in a container at $20^{\circ} \mathrm{C}$ for 24 hours. The seed-steep water was then gently decanted and EC was measured, using an EC meter. Following equation was applied to calculate conductivity per gram of seed weight for each sample (Powell et al., 1984).

$\mathrm{EC}(\mu \mathrm{s} / \mathrm{cm} / \mathrm{g})=[(\mathrm{EC} 1 / \mathrm{SW} 1)+(\mathrm{EC} 2 / \mathrm{SW} 2)] / 2$

All the data were analyzed on the basis of experimental design, using MSTATC software. The means of each trait were compared according to Duncan test at $\mathrm{P} \leq 0.05$. Excel software was used to draw figures.

\section{Results and discussion}

Seed weight of all maize cultivars linearly increased with progressing seed development up to 55 days after flowering. The highest maximum seed weight (mass maturity) was obtained for 'DC-370', followed by 'OSSK-602', 'SC-500' and 'SC-604' cultivars. These variations in seed weight could be largely attributed to differences in seed filling rate (slopes of the linear regressions). Therefore, 'DC-370' with the highest seed filling rate produced the largest seeds (Fig. 1).

Percentages of seed germination of maize cultivars increased with enhancing seed weight up to mass maturity (end of seed filling phase). The highest and the lowest

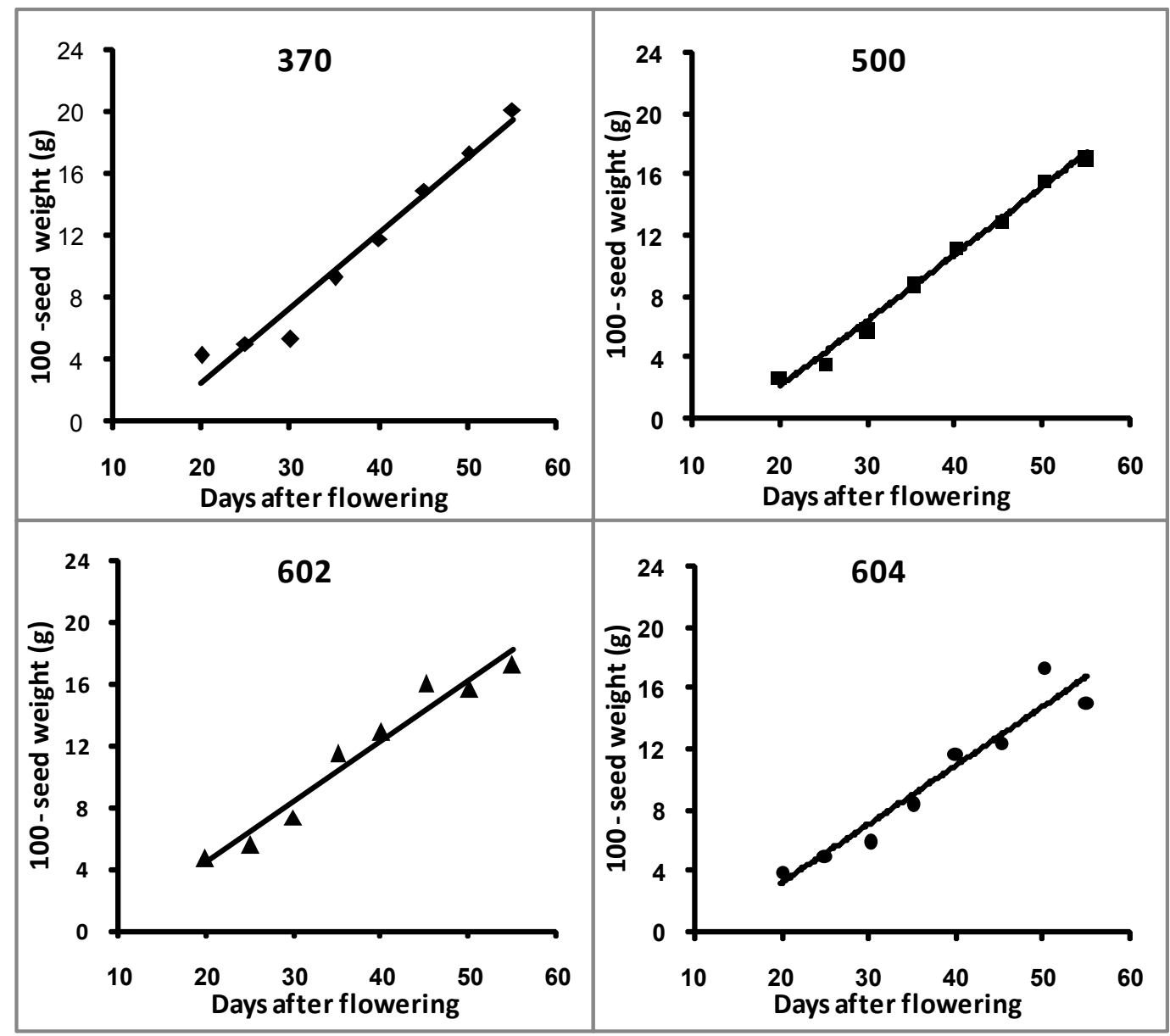

Fig. 1. Changes in seed weight of four maize cultivars at different stages of development 

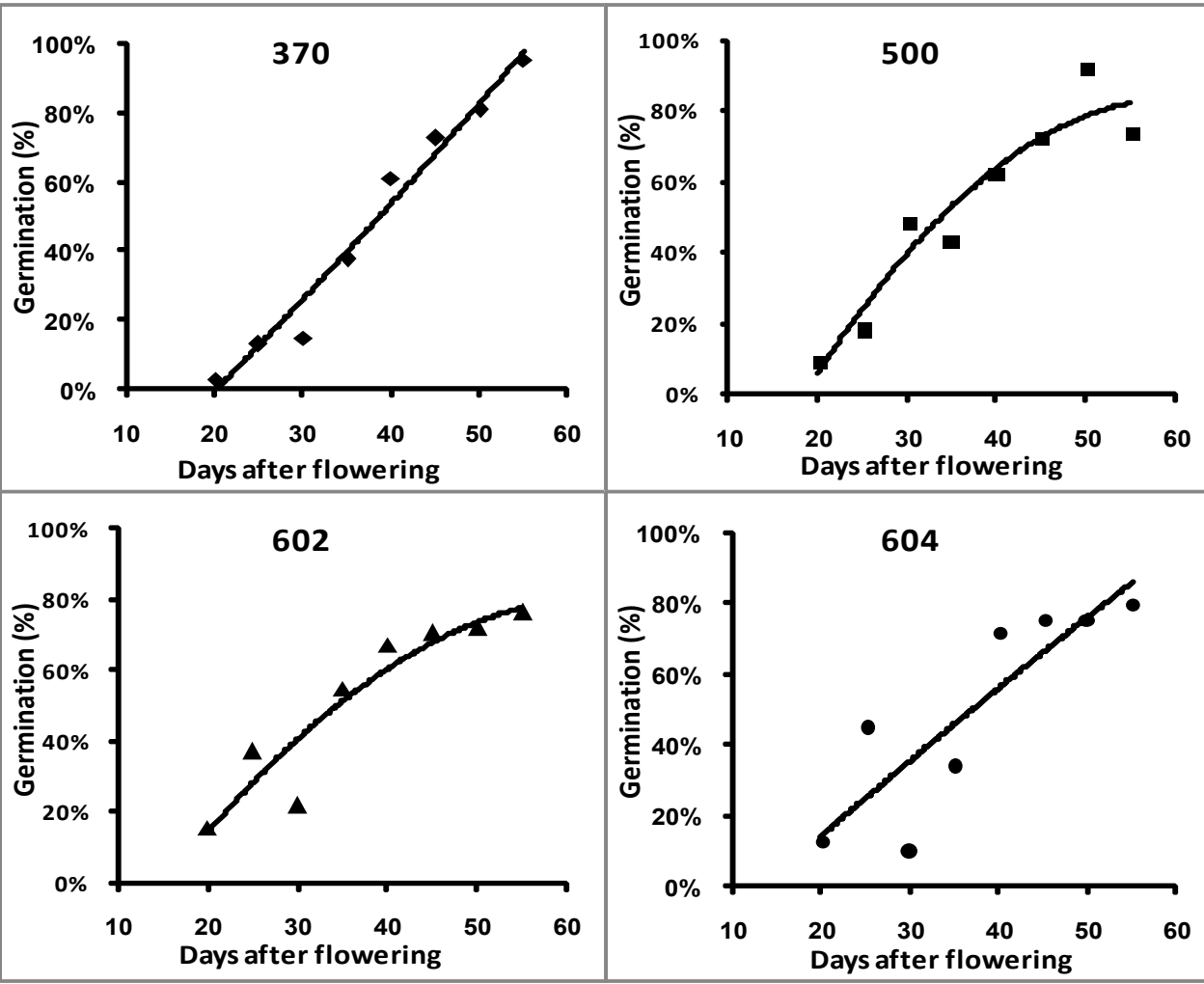

Fig. 2. Changes in seed germination of four maize cultivars at different stages of seed development
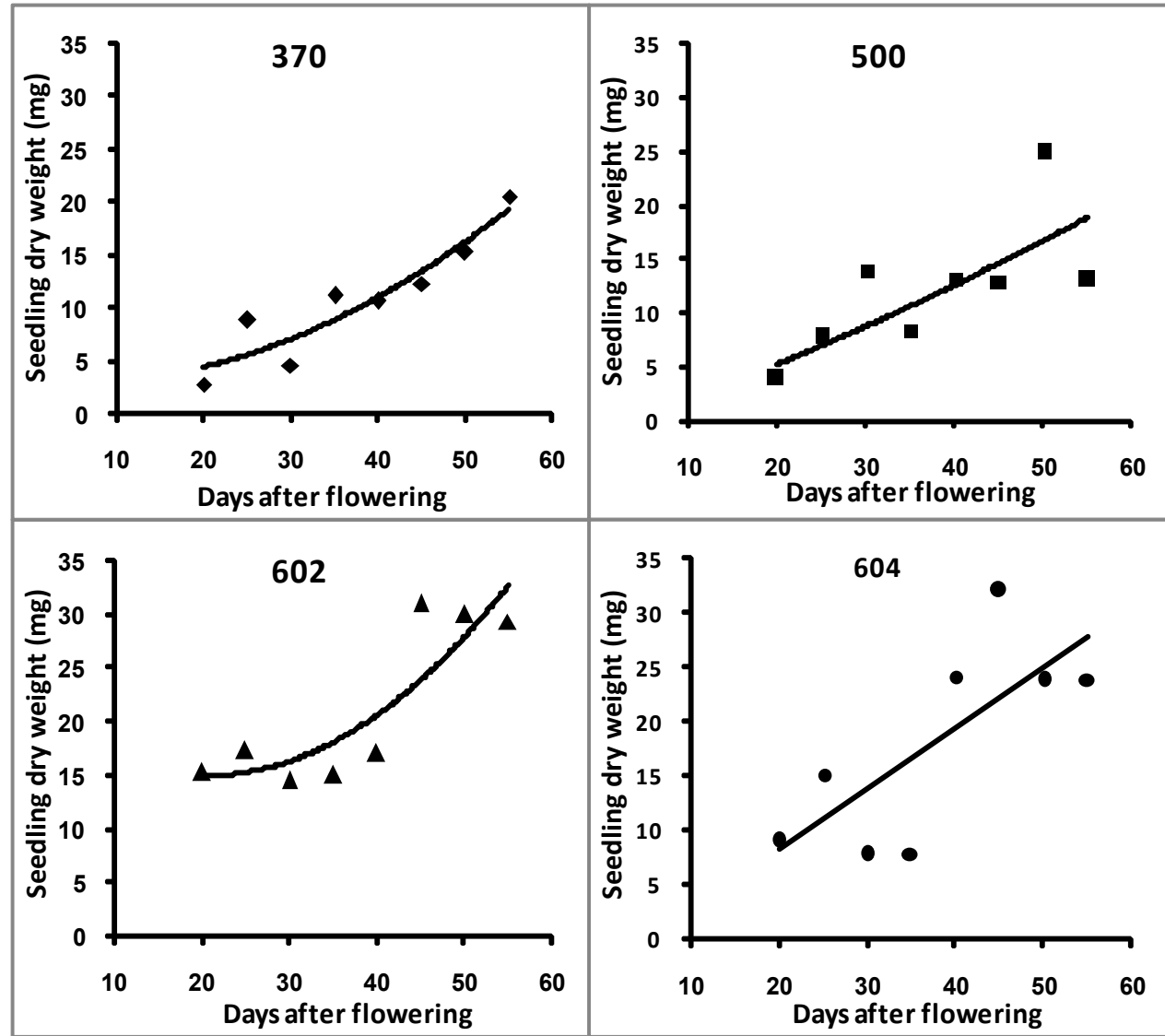

Fig. 3. Seedling dry weight of four maize cultivars at different stages of seed development 


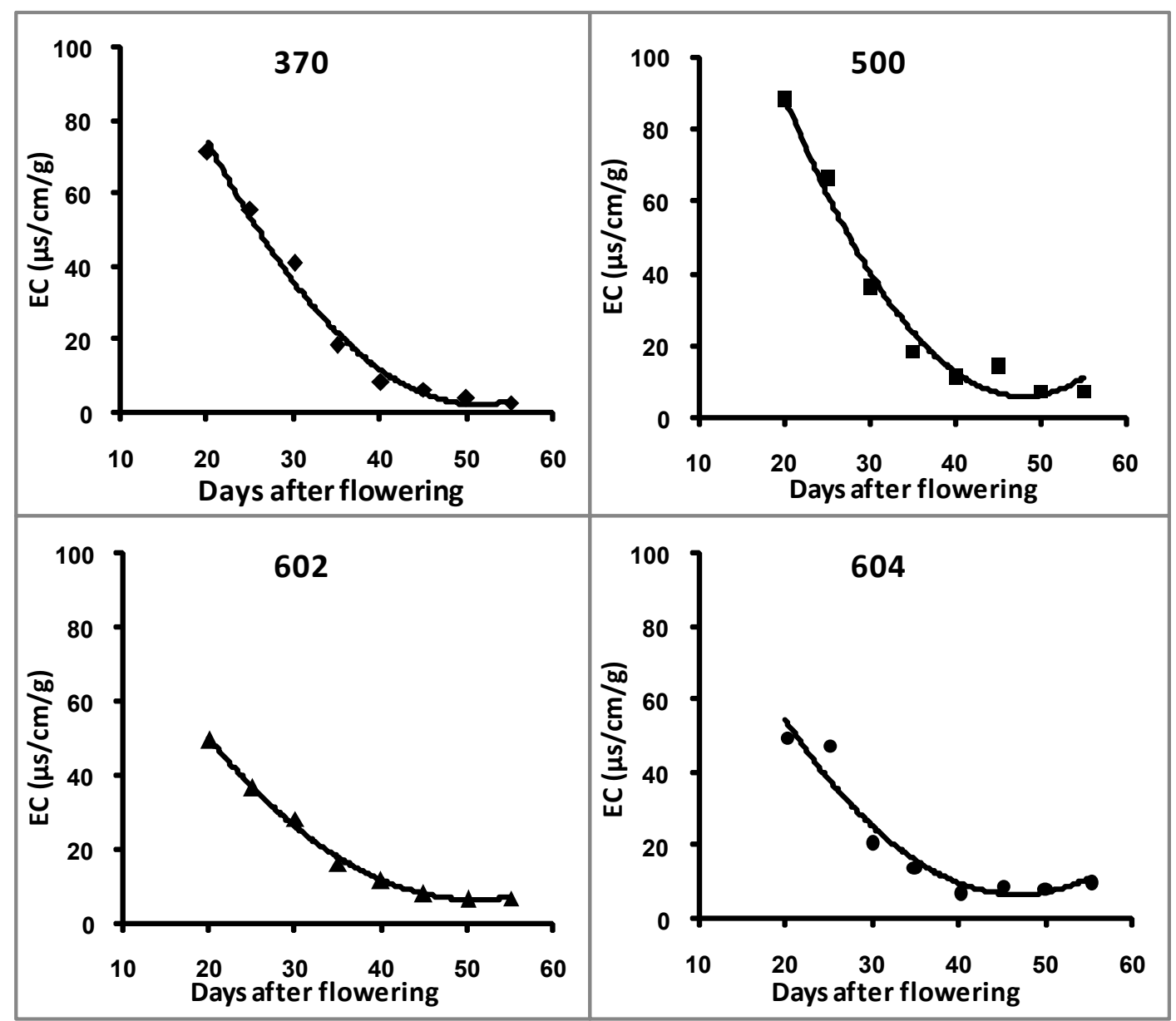

Fig. 4. Changes in electrical conductivity of seed leachates in four maize cultivars at different stages of seed development

germination percentages were recorded for 'DC-370' and 'OSSK-602' cultivars respectively (Fig. 2). Maximum seed germination of all maize cultivars was attained at mass maturity (Fig. 1 and 2). Similar results were reported for soybean (Miles et al., 1988), mungbean (Hamid et al., 1995) and barley (Samarah et al., 2005).

Seedling dry weight of maize cultivars at the early stages of seed development was low, but it was improved with progressing towards mass maturity. Maximum seedling dry weight of 'DC-370' and 'SC-500' was lower than that of 'OSSK-602' and 'SC-604' (Fig. 3). Differences in maximum seedling dry weight among maize cultivars (Fig. 3 ) could be related with variation in genetic constitution, which can strongly influence seed quality and seedling vigor (Perry, 1980b; Ghassemi-Golezani et al., 2010).

Electrical conductivity (EC) of seed leachates for all maize cultivars decreased with improving seed development. Minimum electrical conductivity for 'DC-370', 'SC-500', 'OSSK-602' and 'SC-604' was obtained at 52, 48, 50, 47 days after flowering, respectively (Fig. 4). High electrical conductivity values of seed lots at the early harvests were due to immaturity, which had placed them as low quality seed lots (Hampton et al., 1992; Vieira et al., 2004; Ghassemi-Golezani and Mazloomi-Oskooyi,
2008; Ghassemi-Golezani and Hosseinzadeh-Mahootchy, 2009).

\section{Conclusions}

Maximum seed quality of maize cultivars as measured by seed germination percentage and seedling dry weight was achieved at mass maturity (Fig. 1-3), which is previously termed as physiological maturity (Harington, 1972; Tekrony and Egli, 1997). However, when seed quality was evaluated by electro- conductivity test (Fig. 4), maximum quality was obtained 3-8 days before the end of seed filling phase, depending on cultivar. Thereafter, no considerable changes in seed quality were observed, up to mass maturity. Thus, high quality seeds of maize cultivars could be produced, if seeds were harvested at mass maturity. High quality seeds can perform well in the field, ensuring optimum stand establishment and satisfactory yield under a wide range of environmental conditions (Ghassemi-Golezani et al., 2010b).

\section{References}

Abdalla FH, Roberts EH (1969). The effect of seed storage 
182

conditions on the growth and yield of barley, broad beans and peas. Ann Bot 33:169-184.

Copeland LO, McDonald MB (2001). Seed vigor and vigor tests, p. 121-144. In: Copeland LO, McDonald MB (Eds). Principles of Seed Science and Technology. $4^{\text {th }}$ edition. Kluwer Academic Publishing Group.

Cruz-Garcia F, Gonzalez-Hernandez VA, Molina-Moreno J, Vazquez-Ramos JM (1995). Seed deterioration and respiration asrelated to DNA metabolism in germinating maize. Seed Sci Technol 23:477-486.

Demir I, Ellis RH (1992). Changes in seed quality during seed development and maturation in tomato. Seed Sci Res 2:8187.

Demir I, Ellis RH (1993). Changes in potential seed longevity and seedling growth during seed development and maturation in marrow. Seed Sci Res 3:247-257.

Ellis RH, Pieta Filho C (1992). Seed development and cereal seed longevity. Seed Sci Res 2:9-15.

Ellis RH, Roberts EH (1980). Towards a rational basis for testing seed quality, p. 605-635. In: Hebblethwaite PD (Ed.). Seed Production. Butterworths, London.

Ganguli S, Sen-Mandi S (1990). Some physiological differences between naturally and artificially aged wheat seeds. Seed Sci Technol 18:507-514.

Ghassemi-Golezani K (1992). Effects of seed quality on cereal yields. PhD Thesis. University of Reading, UK.

Ghassemi-Golezani K, Bakhshy J, Raey Y, HosseinzadehMahootchy A (2010a). Seed vigor and field performance of winter oilseed rape (Brassica napus L.) cultivars. Not Bot Hort Agrobot Cluj 38:146-150.

Ghassemi-Golezani K, Hossinzadeh-Mahootchy A (2009). Changes in seed vigor of faba bean (Viciafaba L.) cultivars during development and maturity. Seed Sci Technol 37:713720 .

Ghassemi-Golezani K, Khomari S, Dalil B, HosseinzadehMahootchy A, Chadordooz-Jeddi A (2010b). Effects of seed aging on field performance of winter oil-seed rape. J Food Agric Environ 8:175-178.

Ghassemi-Golezani K, Mazloomi-Oskooyi R (2008). Effect of water supply on seed quality development in common bean (Phaseolus vulgaris var.). J Plant Production 2:117-124.

Ghiyasi M, Miyandoab MP, Tajbakhsh M, Salehzade H, Meshkat MV (2008). Influence of different osmo-priming treatments on emergency and yield of maize (Zea mays L.). Res J Biol Sci 3:1452-1455.

Hamid A, Hashem A, Hamid A, Ahad-Miah MA, Nag BL (1995). Seed development quality, maturity, synchrony and yield of selected mungbean genotypes. Seed Sci Technol 23:761-770.

Hampton JG, Johnstone KA, Eua-Umpon V (1992). Bulk conductivity test variables for mungbean, soybean and french bean seed lots. Seed Sci Technol 20:677-686.

Hanway JJ (1963). Growth stages of corn (Zea mays L.). Agro J 53:225-229

Harington JF (1972). Seed storage and longevity, p. 145- 245. In: Kozlowski TT (Ed.). Seed Biology. Academic Press, NY.
Harris D, Joshi A, Khan PA, Gothakar P, Sodhi PS (1999). Onfarm seed priming in semi-arid agriculture: Development and evaluation in corn, rice and chickpea in India using participatory methods. Exp Agric 35:15-29.

Iqbal N, Basra SHMA, Rehman K (2002). Evaluation of vigor and oil quality in cottonseed during accelerated aging. Int J Agric Biol 4:318-322.

Kim SH, Bin YH, Choe ZR (1989). The use of multiple seed vigor indices to predict field emergence and grain yield of naked and malting barley. J Crop Sci 34:134-141.

Matthews S, Collins MT (1975). Laboratory measures of field emergence potential in barley. Seed Sci Technol 3:863-870.

Miles DF, Tekrony DM, Egli DB (1988). Changes in viability, germination, and respiration of freshly harvested soybean seed during development. Crop Sci 28:700-704.

Perry DA (1977). A vigour test for seeds of barley (Hordeum vulgar) based on measurement of plumule growth. Seed Sci Technol 5:709-719.

Perry DA (1980a). Deterioration of barley seed and its effects on field performance, p. 321-337. In: Hebblethwaite PD (Ed.). Seed Production. Butterworths.

Perry DA (1980b). The concept of seed vigor and its relevance to seed production techniques p. 585-591. In: Hebblethwaite PD (Eds.). Seed Production, Butterworths.

Pieta Filho CP, Ellis RH (1991). The development of seed quality in spring barley in four environments. I. Germination and longevity. Seed Sci Res 1:163-177.

Powell AA, Matthews S, Oliveira A (1984). Seed quality in grain legumes. Adv Applied Biol 10:217-285

Ram C, Wiesner E (1988). Effect of artificial ageing on physiological and biochemical parameters of seed quality in wheat. Seed Sci Technol 16:579-587.

Rench W, Shaw RH (1971). Black layer development in corn. Agro J 63:303-309

Samarah NH (2005). Effects of drought stress on growth and yield of barley. Agro Sustain Develop 25:145-149.

Samarah NH, Al-Kofahi S (2008). Relationship of seed quality tests to field emergence of artificial aged barley seeds in the semiarid mediterranean region. J Agric Sci 4:217-230.

Sanhewe AJ, Ellis RH (1996). Seed development and maturation in Phaseolus vulgaris. I. Ability to germinate and to tolerate desiccation. J Exp Bot 47:949-958.

Tekrony DM, Egli DB (1997). Accumulation of seed vigor during development and maturation, p. 369-384. In: Ellis RH, Black M, Murdoch AJ, Hong TD (Eds.). Basic and Applied Aspects of Seed Biology. Kluwer Academic Publishers, Dordrecht.

Vieira RD, Neto AS, Mudrovitsch de Bittencourt SR, Panobianco M (2004). Electrical conductivity of the seed soaking solution and soybean seedling emergence. Scientia Agricola 61:164-168.

Vieira RD, Paiva-Aguero JA, Perecin D, Bittencourt S (1999). Correlation of electrical conductivity and other vigor tests with field emergence of soybean seedlings. Seed Sci Technol 27:67-75. 